\title{
TERAJU
}

Teraju: Jurnal Syariah dan Hukum

Volume 02 Nomor 01, Maret 2020

DOI: https://doi.org/10.35961/teraju.v2i01.68

\section{Karakteristik Kebutuhan Mustahiq dan Analisis Prioritas Penyaluran Zakat oleh Baznas Kota Tanjungpinang}

\author{
Aris Bintania \\ STAIN Sultan Abdurrahman Kepulauan Riau \\ bintania@stainkepri.ac.id
}

\begin{abstract}
Abstrak
Persoalan dalam artikel ini adalah bagaimana karakteristik kebutuhan mustahiq zakat di Kota Tanjungpinang dan bagaimana mekanisme dan prioritas penyaluran zakat oleh Baznas Kota Tanjungpinang. Berdasarkan penelitian dan penelusuran yang dilakukan di Baznas Kota Tanjungpinang didapatkan keterangan bahwa sejak tahun 2016 kegiatan pengelolan berupa aktifitas pengumpulan dan penyaluran zakat sudah mulai berlangsung, dalam masa kerja lebih dari 2 tahun. Di antara pengalaman para komisioner Baznas Kota Tanjungpinang dalam mengelola, mensosialisasikan, mengumpulkan dan mendistribusikan zakat telah mereka jalani, tidak kurang berbagai persoalan terkait dengan berbagai bentuk persoalan ekonomi umat yang telah mereka terima dan fasilitasi, dalam upaya memberikan solusi nyata bagi para mustahiq zakat di Kota Tanjungpinang berbagai upaya telah mereka lakukan, ini juga sangat terkait dengan persoalan sosialiasi dalam rangka mengarahkan masyarakat Kota Tanjungpinang ke arah terbentuknya masyarakat sadar zakat guna menghimpun dana zakat yang memadai.
\end{abstract}

Kata Kunci: Zakat, Ekonomi Islam, Mustabiq Zakat

\begin{abstract}
Abstrac
The problem in this article is how the characteristics of the needs of zakat in the city of Tanjungpinang and how the mechanism and priority of the distribution of zakat by Baznas Kota Tanjungpinang. Based on research and searches conducted in Baznas Tanjungpinang City is obtained that since the year 2016 the activities of the management of the activity of Zakat collection and channeling has begun to occur, within the employment of more than 2 years. Among the experiences of the Commissioners Baznas Kota Tanjungpinang in managing, socializing, collect and distribute the zakat they have traveled, no less various issues related to the various forms of economic issues of the people they have received and facilitation, in an
\end{abstract}

Teraju: Jurnal Syariah dan Hukum, Vol. 2, No. 1, Maret 2020 
effort to provide a real solution for the Mustahiq Zakat in the city of Tanjungpinang various efforts they have done, this is also very related to the question of socialization in order to direct the people of Tanjungpinang City towards the formation of a zakat-conscious community in order to raise adequate zakat funds.

Keywords: Zakat, Islamic Economics, Mustabiq Zakat

\section{Pendahuluan}

Baznas Kota Tanjungpinang adalah lembaga pengelola zakat yang dibentuk berdasarkan amanah Undangundang Nomor 38 Tahun 1999 tentang Pengelolaan Zakat yang diganti dengan Undang-undang Nomor 23 Tahun 2011. Sebelumnya pengelolaan zakat di Kota Tanjungpinang, dilakukan oleh lembaga yang dibentuk oleh pemerintah daerah yang disebut BAZDA (Badan Amil Zakat Daerah) Kota Tanjungpinang, setelah berlakunya Undang-undang Zakat, badan pengelola Zakat di Kota Tanjungpinang juga mengalami peralihan dari Bazda Kota Tanjungpinang Menjadi Baznas Kota Tanjungpinang.

Periode kepengurusan Baznas saat ini, tahun 2016-2021, adalah periode kepengurusan yang pertama terbentuk berdasarkan hasil seleksi yang dilakukan oleh Pansel Komisioner Baznas yang dibentuk oleh Pemerintah Kota Tanjungpinang pada Tahun 2015 dengan melibatkan dan berkoordinasi dengan Kementerian Agama Kota Tanjungpinang. Selanjutnya setelah lima orang komisioner pimpinan Baznas resmi di SK-kan, terbentuklah kepengurusan Baznas Kota Tanjungpinang dengan menempati kantor di pertokoan Jalan Basuki Rahmat Kota Tanjungpinang.

Sejak tahun 2016 kegiatan pengelolan berupa aktifitas pengumpulan dan penyaluran zakat sudah mulai berlangsung, dalam masa kerja lebih dari 2 tahun. Berdasarkan keterangan, berbagai pengalaman para komisioner Baznas Kota Tanjungpinang dalam mengelola, mensosialisasikan, mengumpulkan dan mendistribusikan zakat telah mereka jalani. Tidak kurang berbagai persoalan terkait dengan berbagai bentuk persoalan ekonomi umat yang telah mereka terima dan fasilitasi, dalam upaya memberikan solusi nyata bagi para mustabiq zakat di Kota Tanjungpinang berbagai upaya telah mereka lakukan, ini juga sangat terkait dengan persoalan sosialiasi dalam rangka mengarahkan masyarakat Kota Tanjungpinang ke arah terbentuknya masyarakat sadar zakat guna menghimpun dana zakat yang memadai.

Berdasarkan hasil survey, peneliti mendapatkan adanya beragam bentuk kebutuhan mustabiq zakat di Kota Tanjungpinang, data itu diperoleh berdasarkan surat formulir pengajuan permohonan bantuan zakat dari masyarakat kota Tanjungpinang, antara lain ada mustabiq yang mengajukan bantuan untuk keperluan biaya pendidikan anak, ada mustahiq yang mengajukan bantuan untuk biaya pengobatan, ada yang minta bantuan karena sudah sekian lama tidak bekerja, ada yang mengajukan bantuan untuk biaya perbaikan rumah tinggal yang hampir roboh, dan yang paling banyak adalah permohonan bantuan untuk mengembangkan usaha berupa modal usaha, pembelian bahanbahan pokok untuk kepentingan usaha dengan membuat berbagai aneka penganan dan kue untuk dijual, pengadaan peralatan, mesin dan alat tangkap bagi mereka yang berprofesi sebagai nelayan dan berbagai kebutuhan-kebutuhan lainnya yang diajukan oleh masyarakat Kota Tanjungpinang. 
Terhadap berbagai macam permohonan bantuan para mustabiq Kota Tanjungpinang yang sangat banyak dan beragam, Baznas Kota Tanjungpinang, dengan mengingat keterbatasan dana zakat yang berhasil dihimpun, membuat sistem dan prosedur penyaluran dengan membuat skala prioritas, antara lain menelusuri kelengkapan administrasi para mustabiq zakat berupa data-data isian formulir, bentuk permohonan bantuan zakat yang diajukan, bentuk usaha yang akan dikembangkan, ketersediaan tempat usaha dan keadaan tempat usaha berikut prospek pengembangannya. Setelah itu Baznas Kota Tanjungpinang melakukan survey lokasi dan asessment kelayakan penerima bantuan untuk nantinya dibawa dalam rapat pleno komisioner Baznas Kota Tanjungpinang.

Selanjutnya berdasarkan hasil musyawarah komisioner Baznas, maka dihasilkanlah daftar mustahiq penerima zakat yang dalam satu tahun dilakukan beberapa tahap penyaluran. Berdasarkan hasil rapat tersebut, tidak semua surat permohonan mustabiq dapat diakomodir, karena keterbatasan dana zakat yang dihimpun, ada sebagian mustabiq yang sebenarnya layak mendapat bantuan tetapi diputuskan belum dapat menerima bantuan kali itu, sehingga diprioriraskan untuk menerima bantuan untuk penyaluran periode berikutnya, di samping itu ada juga berbagai pertimbangan berupa ketidaklayakan pemohon bantuan zakat dan juga bentuk permohonan bantuan yang menurut penilaian Baznas Kota Tanjugpinang tidak realistis.

Tulisan ini bermaksud mengetengahkan kajian tentang Karakteristik Kebutuhan Mustahiq dan Analisis Prioritas Penyaluran Zakat Oleh Baznas Kota Tanjungpinang.

\section{Pembahasan}

A. Profil Baznas Kota Tanjungpinang

Badan Amil Zakat Kota Tanjungpinang dibentuk pertamakali oleh Keputusan Walikota Tanjungpinang Nomor 233 Tahun 2004, Tanggal 7 September, dengan nama awalnya Badan Amil Zakat Daerah (BAZDA). Sejak Tahun 2004 Bazda Tanjungpinang telah menjalani beberapa periode kepengurusan, pertama dari tahun $2004 \mathrm{~s} / \mathrm{d}$ tahun 2009 sebagai ketua adalah H. Said Adnan Zainal yang berlanjut sampai periode kedua dari tahun $2009 \mathrm{~s} / \mathrm{d} /$ 2016. Sebagai tindak lanjut dari Undang-undang Pengelolaan zakat, Bazda kemudian berubah nama menjadi Baznas Kota Tanjungpinang, untuk periode berikutnya, berdasarkan Surat Keputusan Walikota Tanjungpinang Nomor 11 Tahun 2016, pada tanggal 11 Maret 2016 oleh Walikota Tanjungpinang H. Lisdarmansyah, $\mathrm{SH}$, dilantik 5 orang pimpinan Baznas Kota Tanjungpinang Periode 2016-2021. Sebagai Ketua Drs. Muqtafin, M.Pd, dan Unsur Wakil Ketua terdiri dari: Amir Hamzah, Drs. Amril, $\mathrm{H}$, Syahrial Aziz, S.Sos.I, dan Nurbaiti, S.Ag.

$\begin{array}{lcr}\text { Badan Amil Zakat Nasional } \\ \text { (BAZNAS) } & \text { adalah lembaga } \\ \text { pemerintah non-struktural yang }\end{array}$
dibentuk berdasarkan Undangundang Nomor 23 Tahun 2011 dan Peraturan Pemerintah Nomor 14 Tahun 2014 yang memiliki tugas dan fungsi menghimpun dan menyalurkan zakat secara nasional.

Saat ini BAZNAS Kota Tanjungpinang beralamat di deretan pertokoan jalan Basuki Rahmat, Kecamatan Bukit Bestari Kota Tanjungpinang. Kantor Baznas Kota Tanjungpinang menempati sebuah ruko lantai 3 dengan sistem sewa 
pertahun. Selama tiga tahun kepengurusan tercatat telah terjadi tiga kali perpindahan kantor, meskipun masih tetap di deretan pertokoan yang sama.

Adapun struktur Organisasi Baznas Kota Tanjungpinang Periode 2016-2021, unsur pimpinan adalah sebagai berikut:

\section{Ketua:}

Drs. Muqtafin, M.Pd

Wakil I Bidang Pengumpulan :

Amir Hamzah

Wakil II Bidang Penyaluran:

Drs. Amril

Wakil III Bidang Keuangan:

Syahrial Azis, S.sos I

Wakil IV Bidang Administrasi:

Nurbaiti, S.Ag

Visi yang ditetapkan Baznas Kota Tangjungpinang adalah "Menjadi Badan Amil Zakat Nasional (BAZNAS) Kota Tanjungpinang yang Amanah, Transparan dan Profesional'. Dengan Misi berupaya pertama, Meningkatkan kesadaran umat untuk berzakat kepada Amil zakat resmi. Kedua, Meningkatkan penghimpunan dan pendayagunaan zakat sesuai dengan ketentuan syariah dan prinsip manajemen modern. Ketiga, mewujudkan pengelola (ami) yang amanah, profesional, dan kredibel. Keempat, mewujudkan pusat data zakat tingkat Kota Tanjungpinang. Dan kelima, memaksimalkan peran zakat dalam menanggulangi kemiskinan melalui sinergi dan koordinasi dengan lembaga terkait.

$$
\begin{aligned}
& \text { Sebagai Badan Amil Zakat, } \\
& \text { kegitan BAZNAS adalah } \\
& \text { menghimpun Zakat Infak dan } \\
& \text { Sedekah (ZIS) untuk kemudian } \\
& \text { disalurkan kepada mustahiq yang } \\
& \text { berhak menerima sesuai ketentuan } \\
& \text { Agama. Tujuannya adalah untuk } \\
& \text { meningkatkan kesadaran masyarakat }
\end{aligned}
$$

untuk berzakat, mengarahkan masyarakat mencapai kesejahteraan baik fisik maupun non fisik melalui pendayagunaan zakat, meningkatkan status mustabiq menjadi murakki melalui pemulihan, peningkatan kualitas, SDM dan pengembangan ekonomi masyarakat, mengembangkan budaya "memberi lebih baik dari pada menerima" di kalangan mustabiq, mengembangkan manajemen yang amanah, profesional, dan transparan dalam mengelola zakat, menjangkau muqakki dan mustabiq seluas-luasnya, dan memperkuat jaringan antar organisasi pengelolaan zakat.

\section{B. Fiqh Zakat}

Zakat adalah ibadah pokok dalam ajaran Islam, termasuk salah satu rukun Islam. Kata الزكاة berasal dari akar kata زكى yang mengandung beberapa arti seperti membersihkan, bertumbuh dab berkah. ${ }^{1}$ Kata zaka berarti suci, bertambah, berkembang dan menjadi berkah. Orang yang mengeluarkan zakat adalah orang yang membersihkan diri dari hartanya sebagaimana pahalanya juga bertambah dan hartanya diberkahi Allah swt. ${ }^{2}$

Zakat itu di antara hikmahnya adalah untuk membersihkan jiwa dan harta orang yang berzakat. Dalam terminologi syarak zakat diartikan: 'Pemberian tertentu dari harta tertentu kepada orang tertentu menurut syarat-syarat yang ditentukan."

Firman Allah swt. Q.S.: alNur ayat: 21.

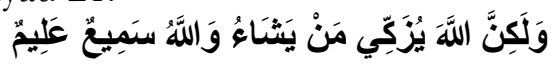

Artinya: “...dan tetapi Allah membersibkan siapa yang dikehendakinya dan Allab Maba Mendengar dan Mengetabui.

1 Amir Syarifuddin, Garis-garis Besar Fiqh, (Jakarta; Kencana, ed-1, cet-2, 2003), h. 37.

2 Hasan Ayub, Fikih Ibadah, Jakarta: Cakra Lintas Media, 2010), h. 345. 
Zakat Secara etimologi dapat diartikan berkembang dan berkah, seperti ungkapan زكا الزرع yang berarti tanaman berkembang dan ungkapan زكت النفقة yang berarti nafkah itu berkah, juga pada ungkapan فلان زكا yang berarti si Fulan banyak kebaikannya. Selain itu zakat juga dapat diartikan mensucikan, ${ }^{3}$ sebagaimana firman Allah swt. dalam Q.S.: Al-Syams: 9.

قََْْ افَفْلَحَحَ مَنْ زَكَكَاهَا

Artinya: "sungguh telah meraih kemenangan orang yang mensucikan jiwanya”.

Maksud ayat di atas adalah membersihkan dari segala noda. Zakat disebut demikian karena harta kekayaan yang dizakati akan semakin berkembang berkat dikeluarkan zakatnya dan doa dari orang yang menerimanya, zakat membersihkan orang yang menunaikannya dari dosa dan membuatnya terpuji, bahkan kelak menjadi saksi atau bukti atas kesungguhan iman orang yang menunaikannya. ${ }^{4}$

Zakat terbagi kepada dua macam, yakni zakat harta (زكاة المال) dan zakat fitrah yang dikeluarkan setiap akhir bulan Ramadhan. ${ }^{5}$

Hukum Zakat adalah wajib 'ain, yaitu kewajiban yang ditetapkan atas diri pribadi yang tidak dapat dibebankan kepada orang lain, meskipun dalam pelaksanaan dapat diwakilkan. ${ }^{6}$

Pada masa permulaan Islam di Mekah, kewajiban zakat masih

3 Abdul Aziz Muhammad Azzam dan Abdul Wahab Sayyed Hawwas, al-Wasith fi Figh alIbadaat (Fiqh Ibadah Thaharah, Shalat, Zakat, Puasa dan Haji. (Terj.), (Jakarta: AMZAH, cet-1, 2009), h. 343. Lihat juga El Madani, Figh Zakat Lengkap, (Jogyakarta: Diva Press, 2013), h. 13.

4 Abdul Aziz Muhammad Azzam dan Abdul Wahab Sayyed Hawwas, al-W asith..., h. 343.

${ }^{5}$ Amir Syarifuddin, Garis...., h. 37.

${ }^{6}$ Amir Syarifuddin, Garis..., h. 38. bersifat global dan belum ada ketentuan mengenai jenis dan kadar harta yang wajib dizakati, zakat sebatas hanya untuk menumbuhkan kepedulian dan kedermawanan umat Islam. Zakat baru benar-benar diwajibkan pada tahun ke-2 Hijriyah, pendapat yang masyhur di kalangan ahli hadis adalah pada bulan bulan Syawal tahun ke-2 Hijriyah.

Banyak sekali perintah Allah swt. untuk membayarkan zakat, dan kebanyakan perintah zakat itu dirangkaikan dengan perintah mendirikan shalat.

a. Q.S.: al-Baqarah: 43

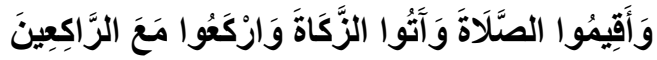
Artinya: "dan dirikanlah shalat dan bayarkan lah rakat da ruku'lah kamu beserta orang-orang yang ruku'."

b. Q.S.: Al-Taubah: 103

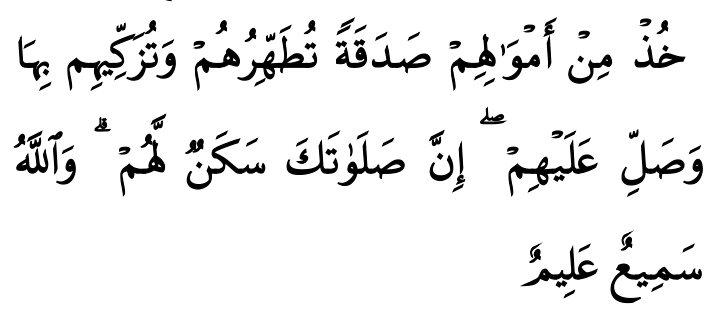

Artinya: "Ambillah zakat dari sebagian harta mereka, dengan zakat itu kamu membersibkandan mensucikan mereka dan mendoalah untuk mereka. Sesunggubnya doa kamu itu (menjadi) ketenteraman jiwa bagi mereka. dan Allab Maha mendengar lagi Maba mengetabui".

c. Q.S.: Al-Baqarah: 267

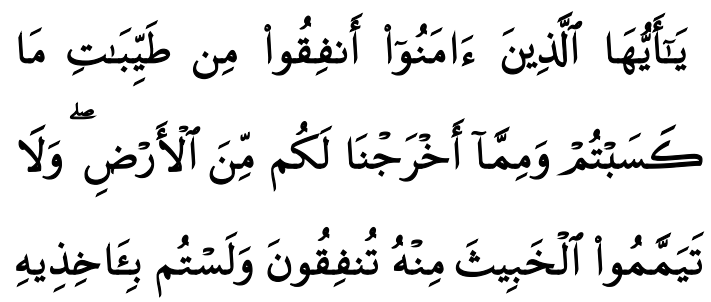

${ }^{7}$ Abdul Aziz Muhammad Azzam dan Abdul Wahab Sayyed Hawwas, al-Wasith, h. 344. 


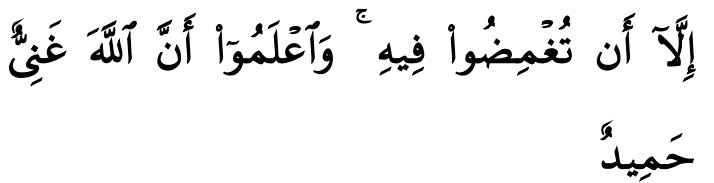

Artinya: "Hai orang-orang yang beriman, nafkabkanlah (di jalan Allah) sebagian dari basil usabamu yang baik-baik dan sebagian dari apa yang Kami keluarkan dari bumi untuk kamu. dan janganlah kamu memilib yang buruk-buruk lalu kamu menafkabkan daripadanya, Padabal kamu sendiri tidak mau mengambilnya melainkan dengan memincingkan $m^{\prime \prime}$ ata terbadapnya. dan ketahuilah, babwa Allab Maba Kaya lagi Maba Terpuij”.

Perintah Allah swt untuk berzakat itu di samping menggunakan lafaz zakat juga menggunakan kata lain, seperti lafaz infaq (Q.S.: alBaqarah: 267), lafaz Sadaqa (Q.S.: alTaubah: 60) dan lafaz 'atu haqqabu (Q.S.: al-An'am: 141). Semua lafaz tersebut mengandung arti zakat. ${ }^{8}$

Adapun dari dalil hadits atau sunnah antara lain adalah sabda Nabi saw.

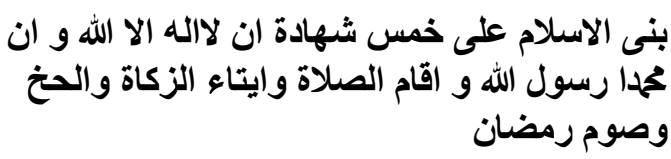

Artinya: "Islam dibangun atas lima pilar: bersyahadat bahwa tiada Tuban melainkan Allab dan Mubammad adalah utusan Allah, mendirikan shalat, menunaikan zakat, haji dan puasa ramadhan.'

Hukum zakat di dalam alQur'an masih bersifat mujmal, tanpa ada penjelasan detail mengenai ketentuan orang yang wajib mengeluarkan, berapa yag wajib dizakati dan apa saja yag wajib di

8 Amir Syarifuddin, Garis..., h. 38.

9 Muttafaq 'Alaih, menurut alDaruquthni, dari narasi Ibnu Umar dengan pernyataan bahwa hadits ini sahih muttashil. AlTalkhish al-Hibr fi Takbrij Ahadits al-Rafi'i al-Kabir II/ 186 . zakati. Penjelasan yang detail dan rinci datang dalam sunnah nabi yang bersifat rinci dan elaboratif. ${ }^{10}$

Berdasarkan kesepakatan ulama, zakat wajib atas orang merdeka, Muslim, baligh, berakal jika dia memiliki satu nishab dengan kepemilikan yang sempurna, genap satu tahun. Zakat sah dengan niat yang dibarengkan ketika pembayaran zakat berdasarkan kesepakatan ulama. Adapun syarat-syarat wajib zakat zakat adalah terhadap orang yang; Islam, Merdeka, Baligh-berakal, memilik harta yang wajib dizakatkan yang telah sampai nisab dan atau haulnya, tidak dalam keadaan berhutang, dan harta yang dimiliki sudah melebihi dari kebutuhan pokok.

Sabda Nabi Muhammad saw, لالَزَكاةَ فِي مَالِ حَنَّى يَحُولَ عَلَيَهِ

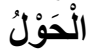

Artinya: "Tidak ada kewajiban zakat pada harta genap satu tabun"

Hitungan haul zakat adalah mengikut tahun qamariyyah dan bukan tahun syamsiyyah berdasarkan kesepakatan ulama, sebagaimana hukum-hukum Islam yang lain seperti puasa dan haji. Para fuqaha madzhab mempunyai pendapatpendapat yang berdekatan seputar genapnya satu tahun.

Tujan dan Hikmah Zakat di antaranya adalah untuk menolong orang yang lemah dan susah agar dia dapat menunaikan kewajibannya terhadap Allah dan terhadap makhluk Allah (masyarakat), menjauhkan diri dari sifat kikir dan akhlak yang tercela, serta mendidik diri agar bersifat mulia dan pemurah dengan membiasakan membayarkan amanat kepada orang yang berhak dan berkepentingan. Selain itu juga

10 Abdul Aziz Muhammad Azzam dan Abdul Wahab Sayyed Hawwas, al-Wasith..., h. 345. 
untuk menjadikan harta yang sudah ditunaikan zakatnya menjadi berkah, yakni berkembang dan berlipat ganda manfaatnya, menjaga kejahatan-kejahatan yang akan timbul dari si miskin dan yang susah dan mendekatkan hubungan kasih sayang dan cinta-mencintai antara si miskin dan si kaya. ${ }^{11}$

Macam-macam zakat antara lain, pertama, adalah zakat fitrah, yaitu zakat yang wajib dikeluarkan oleh setiap muslim laki-laki, perempuan, besar atau kecil, merdeka atau budak pada awal bulan Ramadhan sampai orangorang selesai shalat Idul Fitri, dengan ukuran 1 gantang $(s h a)$ atau dua setengah kilogram bahan makanan pokok untuk siap orangnya.

Kedua adalah Zakat Mal, menurut mayoritas ulama fiqh, adalah setiap barang halal yang bernilai dan setiap orang cendrung untuk memilikinya. ${ }^{12}$ Sehingga ada dua kriteria harta atau mal, yaitu pertama, mempunyai nilai ekonomi untuk ditukar dan bukan sesuatu yang bisa didapatkan dengan percuma, untuk memperolehnya diperlukan imbalan atau jasa yang seimbang. Setiap orang cenderung menyukainnya dan memerlukannya. Kedua, pemanfaatannya dibenarkan syara'.

C. Regulasi Zakat di Indonesia

Regulasi zakat di Indonesia mendapatkan ruangnya seiring dengan bergulirnya era reformasi sejak Tahun 1998, bahwa peristiwa politik yang terjadi saat itu yang

11 Didin hafidhuddin, Zakat dalam perekonomian modern, (Jakarta: Gema insani,2002), h. 34.

12 Oni Sahroni, (dkk), Fikih Zakat Kotemporer, (Depok: PT Rajagranfindo Persada, 2018), h. 46. berujung dengan mundurnya Presiden Republik Indonesia ketika itu, Jenderal Purn Soeharto, yang telah berkuasa selama hampir 32 tahun, mundurnya presiden ketika itu demi memenuhi tuntutan pengunjuk rasa yang tidak hanya menginginkan bergantinya rezim penguasa tetapi juga menghendaki dilakukannya perubahan besar-besaran terhadap konstitusi negara dan peraturan perundang-undangan.

Sejak peristiwa itu maka di Majelis Permusyawaratan Rakat dan Dewan Perwakilan Rakyat melakukan Amandemen terhadap Undangundang Dasar Republik Indonesia. Sebagai akibat dari amandemen terhadap Undang-undang Dasar Republik Indonesia tersebut, maka sebagai tindak lanjutnya secara bertahap dilakukan perubahan dan pembaharuan terhadap berbagai produk peraturan perundangundangan negara, termasuk undangundang di bidang hukum dan peradilan.

Pada tahun 1999 Pemerintah bersama DPR mengesahkan Undangundang Nomor 39 Tahun 1999, tentang Pengelolaan Zakat. Seiring dengan itu juga sebagai pelaksanaan amanat dari amandemen Undangundang Dasar juga diagendakan perubahan perundang-undangan di bidang hukum dan peradilan, telah menghasilkan perubahan yang sangat signifikan terhadap kedudukan, kewenangan dan kompetensi lembaga Peradilan Agama dengan disahkannya undang-undang nomor 35 Tahun 1999 yang merubah Undang-undang Nomor 14 Tahun 1970, tentang Ketentuan Pokok Kekuasaan Kehakiman. Selanjutnya lahir Undang-undang Nomor 3 Tahun 2006 yang merupakan perubahan atas 
Undang-undang Nomor 7 Tahun 1989 tentang Peradilan Agama.

Perubahan penting atas Undang-undang Peradilan Agama adalah bertambahnya kompetensi dan kewenangan Peradilan Agama dalam mengadili perkara Sengketa Ekonomi Syari'ah dan Sengketa Pengelolaan Zakat. Maka Sejak itu peraturan dan regulasi tentang zakat terus mengalami penyempurnaan dan penyesuaian untuk memenuhi tuntutan peraturan perundangundangan agar pelaksanaan pengelolaan zakat benar-benar profensional dan akuntabilitasnya dapat dijaga.

Maka kemudian Undangundang Nomor 38 Tahun 1999 tentang pengelolaan zakat selanjutnya diganti dengan Undang-undang Nomor 23 Tahun 2011. Undangundang ini kemudian diikuti dengan keluarnya berbagai peraturan turunan dari Undang-undang pengelolaan zakat, antara lain:

1. Peraturan Pemerintah RI Nomor 60 Tahun 2010, tentang Zakat atau Pengelolaan Sumbangan Keagamaan yang Sifatnya Wajib yang Boleh Dikurangkan dari Penghasilan Bruto.

2. Peraturan Pemerintah RI Nomor 14 Tahun 2014, tentang Pelaksanaan Undang-undang Nomor 23 Tahun 2011 tentang Pengelolaan Zakat.

3. Keputusan Presiden RI Nomor 8 Tahun 2001, tentang Badan Amil Zakat Nasional.

4. Keputusan Presiden RI Nomor 66/P Tahun 2015, tentang Pengangkatan Anggota Badan Amil Zakat Nasional Periode 2015-2020.
5. Instruksi Presiden RI Nomor 3 Tahun 2014, tentang Optimalisasi Pengumpulan Zakat di Kementerian/Lembaga,

Sekretariat Jenderal Lembaga Negara, Komisi Negara, Pemerintah Daerah, Badan Usaha Milik Negara dan Badan Usaha Milik Daerah Melalui Badan Amil Zakat Nasional.

6. Peraturan Menteri Agama RI Nomor 52 Tahun 2014 yang diubah dengan Peraturan Menteri Agama RI Nomor 69 Tahun 2015, tentang Syarat dan Tatacara Penghitungan Zakat Mal dan Zakat Fitrah Serta Pendayagunaan Zakat untuk Usaha Produktif.

7. Keputusan Menteri Agama RI Nomor 118 Tahun 2014, tentang Pembentukan Badan Amil Zakat Nasional Provinsi.

8. Keputusan Menteri Agama RI Nomor 333 Tahun 2015, tentang Pedoman Pemberian Izin Pembentukan Lembaga Amil Zakat.

9. Peraturan Menteri Agama RI Nomor 5 Tahun 2016, tentang Tatacara Pengenaan Sanksi Administratif dalam Pengelolaan Zakat.

10. Peraturan Menteri Agama RI Nomor 18 Tahun 2016, tentang Organisasi dan Tatakerja Sekretariat Badan Amil Zakat Nasional.

11. Keputusan Direktur Jenderal Bimbingan Masyarakat Islam Nomor DJ.III/499 Tahun 2016, tentang Perubahan Kedua Atas Kepdirjen Bimas Islam Nomor Dj.II/568 Tahun 2014, tentang Pembentukan Badan Amil Zakat Nasional, Kabupaten/Kota SeIndonesia. 
12. Peraturan Menteri Dalam Negeri Nomor 32 Tahun 2011, tentang Pedoman Pemberian Hibah dan Bantuan Sosial yang Bersumber dari Anggaran Pendapatan dan Belanja Daerah.

13. Peraturan Direktur Jenderal Pajak Nomor: PER-33/PJ/2011 yang diubah dengan Perdirjen Pajak Nomor: PER-15/PJ/2012, tentang Badan/Lembaga yang dibentuk atau Disahkan oleh Pemerintah yang Ditetapkan Sebagai Penerima Zakat atau Sumbangan Keagamaan yang Sifatnya Wajib yang Dapat Dikurangkan dari Penghasilan Bruto.

14. Peraturan Badan Amil Zakat Nasional Nomor 1 Tahun 2014, tentang Pedoman Tatacara Pengajuan Pertimbangan Pengangkatan/Pemberhentian

Pimpinan Badan Amil Zakat Nasional Provinsi dan Badan Amil Zakat Nasional Kabupaten/Kota.

15. Peraturan Badan Amil Zakat Nasional Nomor 2 Tahun 2014, tentang Pedoman Tatacara Pemberian Rekomendasi Izin Pembentukan Lembaga Amil Zakat.

16. Peraturan Badan Amil Zakat Nasional Nomor 3 Tahun 2014, tentang Organisasi dan Tatakerja Badan Amil Zakat Nasional Provinsi dan Badan Amil Zakat Nasional Kabupaten/Kota.

17. Peraturan Badan Amil Zakat Nasional Nomor 4 Tahun 2014, tentang Pedoman Penyusunan Rencana Kerja dan Anggaran Tahunan Badan Amil Zakat Nasional, Badan Amil Zakat Nasional Provinsi, Badan Amil Zakat Nasional Kabupaten/Kota.
18. Fatwa Majelis Ulama Indonesia Nomor 8 Tahun 2011, tentang Amil Zakat

19. Fatwa Majelis Ulama Indonesia Nomor 14 Tahun 2011, tentang Penyaluran Harta Zakat dalam Bentuk Aset Kelolaan.

20. Fatwa Majelis Ulama Indonesia Nomor 15 Tahun 2011, tentang Penarikan, Pemeliharaan dan Penyaluran Harta Zakat.

Demikianlah berbagai regulasi tentang pengelolaan Zakat di Indonesia, untuk mewujudkan tata kelola pengelolaan zakat yang memenuhi kemaslahatan masyarakat tampaknya berbagai regulasi akan terus membutuhkan penyesuai dan perubahan sampai keberadaaan Badan Amil Zakat Nasional benar-benar dapat berperan dalam memperbaiki ekonomi dan kesejahteraan masyarakat dan ikut berperan dalam program pengentasan kemiskinan, kebodohan dan keterbelakangan umat Islam di Indonesia.

D. Berkas Pengajuan Permohonan dan Kelengkapan Mustahiq Zakat

Berdasarkan hasil wawancara dan telaah berkas pengajuan bantuan mustabiq zakat Kota Tanjungpinang, prosedur pengajuan permohonan bantuan dana zakat, pertama calon penerima mendatangi sekretariat Baznas Kota Tanjungpinang, mengisi formulir permohonan yang disertai surat permohonan tulis tangan, surat permohonan memaparkan keadaan dan kesulitan yang dialami, usaha yang sudah dan sedang dilakukan dan alasan memohon bantuan. ${ }^{13}$

13 Wawancara dengan Nurbaiti, S.Ag, Pimpinan Bidang Administrasi Baznas Kota Tanjungpinang, Wawancara Oktober 2019 di Kantor Baznas Kota Tanjungpinang. 
Syarat kelengkapan lain adalah: Pas Photo (suami dan isteri), foto copy KTP, Kartu Keluarga dan Surat Nikah, Surat Keterangan dari Lurah yang diketahui Camat atau lembaga resmi lain, ijazah terakhir, rekomendasi dari UPZ Masjid/Surau/Mushalla setempat. Seorang mustabiq juga melampirkan photo tempat usaha dan atau photo produk yang akan dijadikan mata pencarian untuk memenuhi kebutuhan hidupnya, photo orang, tempat atau peralatan/perkakas terkait keperluan pengobatan, perbaikan rumah tinggal, perbaikan tempat usaha, peralatan dan perkakas yang perlu perawatan dan penggantian. Bagian berikutnya adalah uraian tentang bentuk atau jumlah permohonan bantuan yang dimintakan berikut penjelasan untuk keperluan apa bantuan itu diajukan. ${ }^{14}$

E. Bentuk-bentuk Kebutuhan Mustabiq Zakat Kota Tanjungpinang

Berdasarkan studi dokumen pengajuan permohonan zakat di Baznas Kota Tanjungpinang, Tahun 2017-2018, bentuk-bentuk permohonan bantuan dana zakat oleh mustabiq Zakat di Kota Tanjungpinang terdiri dari:

1. Jenis Permohonan Bantuan Modal Usaha

2. Jenis Permohonan Bantuan Alat Tangkap Nelayan

3. Jenis Permohonan Bantuan Untuk Berkebun dan Beternak

4. Jenis Permohonan Bantuan Biaya Hidup Sehari-hari

5. Permohonan Bantuan Biaya Pendidikan Anak

6. Permohonan Bantuan untuk Bayar Hutang

14 Data dokumen formulir dan berkasberkas pengajuan mustabiq masa pengajuan 20182019.
7. Permohonan Bantuan Mengurus Surat Cerai

8. Permohonan Bantuan Bayar Sewa Rumah

9. Permohonan Bantuan Berobat dan Bayar Iuran BPJS

10. Permohonan Bantuan Bedah Rumah/Rehab

11. Permohonan Bantuan Beli Peralatan/Perkakas Rumah Tangga

Dari berkas-berkas isian permohonan para mustahiq zakat, jika dilihat dari pekerjaan mulai dari yang dominan adalah buruh, nelayan, wiraswasta, karyawan swasta, ojek, tidak bekerja, lansia, honorer, tukang bangunan, tani, guru ngaji, supir, dagang dan ada juga PNS dan Pensiunan. Jika dilihat dari isian pekerjaan isteri mayoritas adalah ibu rumah tangga tetapi ada juga yang mengisi profesi sebagai guru honorer, penjahit pakaian, buruh cuci, dan pembantu rumah tangga. Dari keseluruhan pengajuan terdapat banyak mustabiq yang berstatus janda dan duda. Pengajuan permohonan bantuan dana zakat berasal dari wilayah, mulai dari yang terbanyak, adalah dari Kampung BugisSenggarang, Tanjungunggat, Sei Jang, Dompak, Lembah Purnama, Kampung Kolam Batu 8 Atas, Kota Piring, Kenangan Jaya Batu 13, Bumi Air Raja Batu 14, Senggarang, Tugu Pahlawan, RH. Fi Sabilillah, Hanjoyo Putro, Pantai Impian, Bukit Cermin, Batu IX, Kamboja, Juanda, Katamso, Madong, Jl. Kuantan, Gudang Minyak, Wonosari Batu 13, Gatot Subroto, Perum Bukit Raya, Perum Bintan Permai, Basuki Rahmat, RH. Fisabilillah, Sultan Sulaiman, Sukaberenang, Cempedak, Pulau Penyengat, Griya Indonusa, Taman Harapan Indah, Kijang Lama, Karya Baru, Sutan Syahrir, Jl. Nusantara, Sulaiman Abdullah, Sei 
Carang, Karangrejo, Taman Bahagia, Jl.

Bukit Barisan dan Jl. Swadaya.

Adapun jenis usaha yang akan dikembangkan mulai dari yang terbanyak; buka warung sembako/kelontongan harian, jual sarapan pagi, jualan kue, buka usaha kecil-kecilan, kedai jual pulsa dan token listrik, usaha jahit, usaha keripik, jualan jamu, jasa cuci loundry, dagang sayur, jualan air buah, jualan kue keliling, jualan mi lendir, jualan es dan makanan ringan, jual batagor, jualan buah, untuk ngojek, dagang baju, usaha potong rumput, jual es dawet, usaha jahit, jual gas, dan jual sarapan pagi.

F. Mekanisme Penyaluran Zakat oleh Baznas Kota Tanjungpinang

Berdasarkan Keterangan yang didapat dari unsur pimpinan Baznas Kota Tanjungpinang, dan didukung oleh dokumen yang tersedia, bahwa untuk memutuskan disetujui tidaknya permohonan bantuan yang diajukan oleh masyarakat, Baznas Kota Tanjungpinang mengadakan rapat pimpinan yang membahas satu persatu permohonan bantuan yang diajukan mustahiq.

Untuk membahas usulan bantuan dari mustahiq zakat, berkas permohonan yang telah diajukan oleh masyarakat mustabiq, yang sudah dilengkapi dengan berbagai kelengkapan surat dan data pendukung disusun sesuai nomor urut permohonan. Sebelumnya juga setiap pemohon telah terlebih dahulu dilakukan survei kelayakan dengan cara pihak Baznas langsung turun ke lokasi tempat tinggal di mana mustahiq zakat berdomisili, yang dalam pelaksanaannya di bawah tanggung jawab wakil ketua bidang penyaluran.

Untuk keperluan survei Baznas Kota Tanjungpinang menyediakan Surat berita acara survei yang harus diisi oleh petugas yang melaksanakan survey lapangan. Berita Acara Survey merupakan sebuah formulir isian yang di atasnya mencantumkan kepala surat berupa Kop yang mencantumkan logo dan alamat Baznas Kota Tanjungpinang. Di bagian atas form isian terdapat keterangan tanggal diajukannya permohonan mustabiq dan nomor berkas pengajuan. Selanjutnya ada isian tentang hari atau tanggal survey dilakukan dan nama petugas yang melakukan survey.

Format isian survey berisi keterangan identitas dari mustahiq, nama dan usia suami dan nama isteri, lama domisili di Tanjungpinang, pekerjaan utama dan sampingan, latar belakang pendidikan, identitas dan keterangan anggota keluarga yang menjadi tanggungan, jumlah penghasilan perbulan dan alamat tempat tinggalnya.

Selanjutnya terdapat form isian tentang keadaan dan kondisi perekonomian mustahiq dalam hal:

1. Tempat Tinggal dan perlengkapan rumah tangga.

Untuk tempat tinggal, petugas mensurvei ukuran rumah yang dipetakan ke dalam 4 (empat) kategori; sangat kecil (luas $\leq 4 \mathrm{~m} 2$, kecil 4-6 m2, sedang 6-8 $\mathrm{m} 2$ dan besar $\geq 8 \mathrm{~m} 2$. Spesifikasi dinding rumah terdiri dari apakah terbuat dari bambu, semi permanen dan permanen (beton). Spesifikasi lantai apakah berupa lantai tanah, lantai panggung (kayu), lantai semen atau kah lantai keramik. Atap rumah apakah terbuat dari Rumbia/Ijuk, Genteng, Seng atau Asbes. Tentang Kepemilikan rumah apakah menumpang, kontrak, rumah keluarga, atau rumah sendiri. Keadaan dapur apakah alat memasaknya tungku (kayu bakar), kompor minyak, 
kompor gas/listrik. Keadaan kursi tamu apakah lesehan, balai bambu, kayu sofa. Apakah memiliki kebun dan jika memiliki berapa luas kebun (dari di bawah $1000 \mathrm{M}^{2}$, antara $1000 \mathrm{~s} / \mathrm{d} 5000 \mathrm{M}^{2}$ dan di atas $5000 \mathrm{M}^{2}$. Alat elektronik apakah memiliki radio, tape, Televisi, VCD, atau handphone. Apakah ada kendaraan yang dimiliki, mulai dari sepeda kayuh, sepeda motor, mobil. Selanjutnya jika mustabiq memiliki hewan ternak mulai dari unggas, kambing/domba, sapi/kerbau. Kemudian simpanan mustabiq yang dimiliki mulai dari tabungan, perhiasan emas dan terakhir data tentang lain-lain semisal data bantuan yang pernah didapat dalam lima tahun terakhir. ${ }^{15}$

2. Catatan Tambahan

Yaitu berupa format isian yang dikosongkan untuk diisi oleh petugas survey yang bersifat narasi berupa keterangan tambahan.

3. Hasil Penelitian

Merupakan bagian kesimpulan hasil survey berupa kotak opsi yang diconteng, apakah layak dibantu, perlu peninjauan kembali atau tidak layak dibantu. Jika opsi yang dipilih petugas survey adalah layak dibantu, maka ada bagian rekomendasi petugas survey mengenai estimasi bantuan yang diberikan, bentuk atau jenis bantuannya.

G. Analisis dan Prioritas Penyaluran Zakat oleh Baznas Kota Tanjungpinang

Berdasarkan wawancara dari responden penelitian, yaitu unsur pimpinan Baznas Kota

15 Diilustrasikan dari format formulir isian Berita Acara Survey Baznas Kota Tanjungpinang.
Tanjungpinang, peneliti mendapatkan banyak penjelasan terkait kebijakan penyaluran zakat di Baznas Kota Tanjungpinang.

Pertama bahwa periode kepengurusan Baznas saat ini, periode kepengurusan 2016-2021, mereka telah memasuki tahun ke-tiga periode kepengurusan. Masa kepengurusan saat ini adalah masa peralihan dari pengelolaan zakat di Kota Tanjungpinang yang sebelumnya bernama Badan Amil Zakat Daerah (Bazda) yang dibentuk oleh Pemerintah Kota Tanjungpinang. Pada tahun 2016, tahun pertama kepengurusan, adalah masa kerja yang masih bersifat penyesuaian, setelah perubahan nama dari Badan Amil Zakat Daerah ke Badan Amil Zakat Nasional yang diikuti dengan peralihan kepengurusan, selanjutnya dilakukan serah terima aset dan pembukuan dana zakat sebelumnya yang disertai dengan penyerahan dana zakat yang belum disalurkan ke pengurus Badan Amil Zakat yang baru. $^{16}$

Di tahun pertama dan kedua, penyaluran zakat dilakukan sebanyak dua kali penyaluran yang dibagi dalam dua semester, pertimbangannya adalah masih minimnya jumlah dana zakat yang terkumpul di banding jumlah permohonan mustahiq. Meskipun begitu, dibanding jumlah pengumpulan di tahun sebelumnya di Era Bazda jumlah pengumpulan di tahun 2015 tercatat berjumlah Rp. 350 Juta, pada Tahun 2016 setelah peralihan ke Baznas jumlah pengumpulannya sudah meningkat menjadi Rp. 750 Juta dan di tahun 2017 pengumpulan dana zakat

16 Wawancara dengan Amir Hamzah, Wakil Ketua II Bidang Pengumpulan Baznas Kota Tanjungpinang, pada hari Tanggal Tahun 2019 bertempat di Kantor Baznas Kota Tanjungpiang. 
meningkat signifikan menjadi Rp. 1,2 Miliar Rupiah, melebihi proyeksi target pencapaian yang ditetapkan unsur pimpinan Baznas tahun itu yang menargetkan pengumpulan sebesar 900 Juta Rupiah.

Memasuki tahun ketiga, seiring dengan kian meningkatnya dana zakat yang terkumpul, penyaluran dana zakat tidak lagi dilakukan dalam hitungan satu semester, kebijakan ini didasarkan kepada hasil evaluasi dan masukan dari masyarakat tentang rentang waktu penyaluran yang terlalu lama sehingga seringkali masyarakat merasakan penyaluran dana zakat tidak tepat guna karena tidak bisa mengatasi kebutuhan mereka yang mendesak karena harus menunggu waktu penyaluran yang terjadwal. Maka selanjutnya, di tahun ketiga, Baznas Kota Tanjungpinang meningkatkan frekwensi penyaluran menjadi empat kali dalam setahun,yakni setiap tiga bulan sekali, dan untuk kasus-kasus yang bersifat mendesak mulai dilakukan penyaluran yang bersifat langsung, tanpa menunggu periode penyaluran pertiga bulan itu. ${ }^{17}$

Jika dilihat dari wilayah domisili para mustabiq, wilayah yang menjadi kantong-kantong konsentrasi tempat tinggal mustahiq, pengajuan permohonan penyaluran dana zakat mulai dari wilayah yang terbanyak adalah; Kampung Bugis, Tanjung Unggat, Kampung Kolam Sei Jang dan Kampung Kelam Pagi Dompak. Selebihnya adalah permohonan mustahiq yang berasal dari berbagai wilayah di Kota Tanjungpinang. ${ }^{18}$

Ibid.

17 Wawancara dengan Amir Hamzah......,

18 Wawancara dengan Drs. Amril, Wakil

Ketua III Bidang Pendistribusian dan
Jika dilihat dari konsentrasi wilayah tempat tinggal mustahiq, pada umumnya mereka adalah masyarakat yang bertempat tinggal di wilayah pesisir tepi pantai Kota Tanjungpinang, pekerjaan utama mereka adalah masyarakat nelayan, buruh dan pekerja serabutan dan pedagang kedai dan kelontong kecilkecilan.

Bentuk-bentuk permohonan dan tujuan penggunaan juga terkait dengan pekerjaan utama tersebut, yakni berupa alat tangkap nelayan, alat dan perkakas untuk usaha kecilkecilan, modal usaha, dan sebagian lagi permintaan bantuan dana benarbenar untuk digunakan untuk mencukupi biaya hidup sehari-hari, termasuk biaya kesehatan dan pendidikan anggota keluarga.

\begin{tabular}{llr}
\multicolumn{2}{c}{ Namun, di } & lapangan \\
terkadang & Surveyor & Baznas \\
menemukan & beberapa & bentuk \\
pengajuan & yang memerlukan
\end{tabular}
kewaspadaan pihak Baznas Kota Tanjungpinang, seperti adanya pengajuan mustabiq yang dikoordinir oleh oknum-oknum warga masyarakat tempat asal pengajuan. Dugaan ini muncul karena dalam waktu tertentu secara beriringan dan bergantian datang warga masyarakat dari wilayah yang sama yang mengajukan permohonan dengan diantar oleh orang-orang tertentu, ada indikasi orang tersebut menjadi pemberi informasi dan pemberi petunjuk tentang tatacara pengajuan bantuan ke Baznas dengan motif mendapat imbalan dari mustahiq yang mendapatkan bantuan.

Terhadap permasalahan ini, berdasarkan penjelasan para pimpinan Baznas Kota Tajungpinang, pada dasarnya mereka tetap memproses

Pemberdayaan, Hari Rabu Tanggal 6 November 2019 di Baznas Kota Tanjungpinang. 
pengajuan bantuan mustabiq sesuai Standar Operasional Prosedur yang telah ditetapkan. Jika hasil survey lapangan menunjukkan keadaan perekonomian warga tersebut memang layak sebagai penerima dana zakat, maka pihak Baznas akan tetap menyalurkan bantuannya. Namun, sebagai bentuk kehati-hatian, dalam penyerahan dana zakat, Baznas Kota Tanjungpinang mengambil kebijakan dengan cara penyerahan bantuan secara langsung kepada mustabiq sehingga mempersempit praktik percaloan dalam pengajuan bantuan dana zakat. ${ }^{19}$

Selain itu terdapat juga pengajuan dari masyarakat yang bersifat ikut-ikutan, padahal ketika survey lapangan dilakukan, hasil observasi dan informasi yang didapat menunjukkan yang bersangkutan adalah warga yang perekonomiannya sudah memadai dan tidak layak ditetapkan sebagai mustabiq, indikasinya adalah keadaan rumah yang ditempati, bukan hanya rumah milik sendiri, tetapi ukuran dan keadaan rumah jauh di atas keadaan rumah-rumah tetangga warga yang mengajukan bantuan. Bahkan ada warga yang mengajukan itu, berdasarkan keterangan warga sekitar, memiliki usaha yang memadai seperti punya kedai besar dan bahkan ada yang memiliki usaha rumah kontrakan. Berdasarkan tanya jawab dalam proses survey, ada indikasi yang bersangkutan hanya ikut-ikutan saja, barangkali bisa juga mereka dapat bantuan. ${ }^{20}$

19 Wawancara dengan Amir Hamzah (Wakil I), Drs, Amril (Wakil II) dan Nurbaiti S.Ag, (Wakil IV Bidang Administrasi) Baznas Kota Tanjungpinang, Hari Rabu, 6 November 2019.

20 Wawancara dengan Amril, Wakil Ketua II Bidang Penyaluran dan Pemberdayaan..., hari Rabu tanggal 6 November 2019.
Fenomena berikutnya adalah adanya beberapa kasus mustahiq yang telah mendapatkan bantuan dana zakat baik bantuan tunai dan juga ada bantuan berupa barang, setelah mendapatkan bantuan ternyata kemudian tidak menggunakannya sesuai peruntukan ketika permohonan diajukan, bahkan ada mustahiq yang ketika mendapat bantuan barang, seperti sampan, jaring, mesin dan atau perkakas dan peralatan yang sedianya akan digunakan untuk berusaha malah dijual untuk diuangkan kembali.

Dalam suatu keadaan, pernah juga, Baznas Kota Tanjungpinang dihadapkan kepada permohonan bantuan dana zakat dari masyarakat yang jumlahnya sangat banyak, sementara ada keterbatasan penyaluran karena penghimpunan dana zakat yang masih kurang, sebagai bentuk seleksi dan prioritas penyaluran, pihak baznas menyeleksinya dengan melakukan penambahan persyaratan berupa surat keterangan layak mendapat bantuan dari pengurus masjid setempat, hal ini dilakukan untuk lebih memprioritaskan mustahiq yang lebih menjaga amal ibadahnya dari mustahiq yang kurang mempedulikan pelaksanaan amal ibadah. Surat keterangan dari pengurus masjid menjadi indikator bagi Pimpinan Baznas untuk melakukan seleksi dari segi pelaksanaan kewajiban dan perintah agama. Kiat ini terbukti efektif untuk mengetahui mana mustahiq yang memiliki interaksi dengan warga melalui sarana ibadah.

Temuan berikutnya adalah adanya pengajuan bantuan dari keluarga yang isterinya mengajukan permohonan bantuan tanpa sepengetahuan suaminya, terkadang ketika survey lapangan dilakukan 
terjadi salah paham antara suami isteri tersebut dan juga munculnya salah sangka terhadap petugas survey lapangan yang ditugaskan oleh Baznas Kota Tanjungpinang. Ada juga suami yang sebagai kepala keluarga justru menyatakan tidak setuju dan menolak adanya bantuan dari Baznas, di samping tidak adanya komunikasi yang baik dalam keluarga, juga karena didorong oleh rasa malu sang suami menerima bantuan zakat.

Keadaan ini, berdasarkan penjelasan para komisioner Baznas Kota Tanjungpinang, justru menjadi perhatian mereka, karena panduan rencana strategis Baznas tentang penyaluran memang tidak hanya difokuskan kepada kalangann mustahiq yang aktif meminta bantuan, tetapi juga melakukan penelusuran mandiri dengan mencari dan mengidentifikasi mustabiq yang belum terdata dan tidak mengajukan bantuan. Di lapangan, para komisioner Baznas seingkali menemukan mustabiq yang sebenarnya sangat layak menerima dana zakat tetapi, tidak pernah mengajukan permohonan bantuan dana zakat, bisa disebabkan karena kurangnya sosialisasi dan informasi tetapi ada juga mustabiq yang tidak mau mengajukan bantuan dana zakat karena malu dan segan. Informasi dari tetangga dan warga sekitar turut membantu Baznas dalam mengidentifikasi dan mengakomodir kalangan mustahiq yang menahan diri dari meminta bantuan.

Fenomena berikutnya adalah warga yang mengajukan permohonan bantuan atas nama bantuan asnaf Ibnu Sabil untuk mendapat biaya kepulangan, tetapi ternyata itu modus untuk mendapatkan uang, sehingga Baznas mengantisipasinya dengan membelikan bantuan berupa tiket dan sekedar uang bekal di perjalanan.
Dengan cara itu pun terkadang masih ada yang menjual kembali tiketnya dan ternyata dia masih berada di Kota Tanjungpinang.

Di samping itu ada juga warga yang mengajukan bantuan dana zakat yang berasal dari Aparatur Sipil Negara/ASN-PNS dan Pensiunan, menurut pimpinan Baznas, pengajuan permohonan bantuan dana zakat dari kalangan ASN dan Pensiunan, disebabkan oleh persoalan banyaknya hutang piutang yang memberatkan, karena meminjam ke rentenir. Dalam kasus tertentu ada yang terikat kepada beberapa orang rentenir sekaligus, sehingga tidak mungkin lagi untuk menutupinya dari gaji/pensiun bulanan. Ssoal jeratan hutang rentenir bukan hanya dialami oleh ASNPensiunan, hal ini juga banyak dialami oleh masyarakat biasa yang juga mengajukan bantuan pelunasan hutang ke Baznas Kota Tanjungpinang.

Mustabiq zakat yang datang ke Baznas Kota Tanjungpinang, tidak hanya yang datang dengan inisiatif sendiri, tetapi banyak juga mustabiq yang diarahkan datang ke Baznas oleh pihak-pihak tertentu seperti arahan dari kalangan masyarakat, arahan dari muzakki yang membayarkan zakatnya di Baznas Kota Tanjungpinang, dari pegawai Dinas Sosial Kota Tanjungpinang, arahan dan petunjuk dari pegawai atau staf kelurahan, dan dari arahan staf/pegawai Rumah Tahanan Negara.

Temuan-temuan ini menjadi catatan dan perhatian Baznas Kota Tanjungpinang untuk selalu melaksanakan prinsip kehati-hatian dalam penyaluran zakat karena mengingat dana zakat yang dikumpulkan oleh Baznas adalah amanah yang harus selalu dijaga dan 
nantinya akan dipertanggungjawabkan dunia akhirat. ${ }^{21}$

Demikianlah penjelasanpenjelasan dari Para Pimpinan Baznas Kota Tanjungpinang yang menunjukkan problematika dan dinamika penyaluran dana zakat di Kota Tanjungpinang. Berbagai gejala dan fenomena yang muncul menjadi bahan untuk evaluasi dan refleksi oleh Baznas Kota Tanjungpinang dalam mewujudkan Penyaluran Dana Zakat yang berorientasi pemberdayaan mustabiq yang diharapkan tidak hanya berkontribusi dalam program pengentasan kemiskinan tetapi juga bertujuan menjadikan warga mustahiq ke depan dapat memperbaiki perekonomiannya sehingga bukan lah suatu hal yang mustahil ke depan si mustahiq akan menjadi murakki yang membayarkan zakatnya di Baznas Kota Tanjungpinang.

\section{Kesimpulan}

Berdasarkan penelitian yang telah dilakukan maka dapatlah disimpulkan bahwa: karakteristik kebutuhan mustahiq zakat bervariasi berdasarkan latar belakang profesi dan proyeksi usaha dan pengembangan ekonomi yang dapat dilakukan oleh mustahiq zakat.

Mustahiq zakat di baznas Kota Tanjungpinang adalah masyarakat dari kalangan fakir dan miskin dari kalangan pekerja serabutan, buruh, ibu rumah tangga, nelayan, janda dan pengangguran.

Bentuk bantuan yang dimohonkan adalah bantuan berupa modal usaha kecilkecilan,berjualan dengan membuka kedai dan atau membuat kue dan makanan, permohonan bantuan berupa alat tangkap dan perlengkapan nelayan seperti sampan, mesin sampan, jaring, keramba, kawat untuk membuat bubu, dll.

21 Wawancara dengan Amir Hamzah, Wakil Ketua I Baznas Kota Tangjungpinang.
Adapun mekanisme penyaluran zakat dari pengelola Baznas Kota Tanjungpinang, setelah masyarakat mustahiq mengisi formulir permohonan bantuan dan melengkapi syarat kelengkapan berkas, pihak Baznas Kota Tanjungpinang terlebih dahulu melakukan survey ke alamat tempat tinggal mustahiq dengan berita acara survey yang berisi keadaan ekonomi mustahiq dan kesimpulan rekomendasi dari petugas survey tentang kelayakan mustahiq menerima bantuan. Setelah itu dalam satu periode penyaluran dana zakat, unsur pimpinan Baznas Kota Tanjungpinang melakukan rapat pleno untuk membahas satu persatu berkas permohonan mustahiq untuk ditetapkan apakah calon pengusul permohonan bantuan ditetapkan sebagai penerima dana zakat atau tidak.

Memandang hasil penelitian yang telah didapat dalam penelitian ini, penulis merasa perlu memberi saran-saran kepada berbagai pihak yang terkait, di antaranya kepada pihak Baznas Kota Tanjungpinang untuk ke depan lebih mengembangkan pelayanan bantuan zakat dengan metode survey mandiri dengan melacak dan menemukan sendiri masyarakat yang layak dan perlu mendapatkan bantuan dan pembinaan dari Baznas Kota Tan jungpinang.

\section{Daftar Pustaka}

Buku-Buku:

Abdillah Ahsan, SE, MSE dkk, Pemetaan Mustabiq, Muzakeki dan Potensi Pemberdayaan di Indonesia, Laporan Penelitian 2017.

Abdul Aziz Muhammad Azzam dan Abdul Wahab Sayyed Hawwas, alWasith fi Figh al-Ibadaat (Fiqh Ibadah Thaharah, Shalat, Zakat, Puasa dan Haji. (Terj.), (Jakarta: AMZAH, cet1, 2009).

Al-Talkhish al-Hibr fi Takbrij Ahadits alRafi'i al-Kabir II/186. 
Amir Syarifuddin, Garis-garis Besar Figh, Jakarta; Kencana, ed-1, cet-2, 2003).

Didin hafidhuddin, Zakat dalam perekonomian modern, (Jakarta: Gema insani,2002).

El Madani, Fiqh Zakat Lengkap, (Jogyakarta: Diva Press, 2013).

Hasan Ayub, Fikih Ibadah, (Jakarta: Cakra Lintas Media, 2010).

Hasbiyallah, Figh dan Ushul Fiqh, (Bandung: PT Remaja Rosdakarya, 2013).

Hasbiyallah, Fiqh dan Ushul Fiqh, (Bandung: PT Remaja Rosdakarya, 2013).

Kamus Besar Bahasa Indonesia Pusat Bahasa, (Jakarta: PT Gramedia Pustaka Utama, 2008).

Kementerian Agama RI, Panduan Orgasnisasi Pengelolaan Zakat, Dirjen Bimas Islam: Direktorat Pemberdayaan Zakat, Tahun 2016

Muhammad Sayyid Sabiq, Fikih Sunnah, (Jakarta: Pena Pundi Aksara, 2008).

Oni Sahroni, (dkk), Fikih Zakat Kotemporer, (Depok: PT Rajagranfindo Persada, 2018).

Rencana Strategis Baznas Kota Tanjungpinang Tahun 2016-2020. tp. 2016.

Syahril Jamil, Prioritas Mustabiq Zakat Menurut Teungku Hasbi As-Shiddeiqy, Jurnal Istinbath Nomor 16/Tahun XIV/Juni/2015/h. 145-159.

Wahbah az-Zuhaili, Figh Islam $W a$ Adillatubu (Darul fikir:

Damaskus,2007).

Peraturan Perundang-undangan:

Undang-undang Nomor 39 Tahun 1999, tentang Pengelolaan Zakat yang diganti dengan Undang-undang Nomor 23 Tahun 2011.

Undang-undang Nomor 23 Tahun 2011, tentang Pengelolaan Zakat

Peraturan Pemerintah RI Nomor 60 Tahun 2010, tentang Zakat atau
Pengelolaan Sumbangan Keagamaan yang Sifatnya Wajib yang Boleh Dikurangkan dari Penghasilan Bruto.

Peraturan Pemerintah RI Nomor 14

Tahun 2014, tentang Pelaksanaan Undang-undang Nomor 23 Tahun 2011 tentang Pengelolaan Zakat.

Keputusan Presiden RI Nomor 8 Tahun 2001, tentang Badan Amil Zakat Nasional

Keputusan Presiden RI Nomor 66/P Tahun 2015, tentang Pengangkatan Anggota Badan Amil Zakat Nasional Periode 2015-2020.

Instruksi Presiden RI Nomor 3 Tahun 2014, tentang Optimalisasi Pengumpulan Zakat di Kementerian/Lembaga, Sekretariat Jenderal Lembaga Negara, Komisi Negara, Pemerintah Daerah, Badan Usaha Milik Negara dan Badan Usaha Milik Daerah Melalui Badan Amil Zakat Nasional.

Peraturan Menteri Agama RI Nomor 52 Tahun 2014 yang diubah dengan Peraturan Menteri Agama RI Nomor 69 Tahun 2015, tentang Syarat dan Tatacara Penghitungan Zakat Mal dan Zakat Fitrah Serta Pendayagunaan Zakat untuk Usaha Produktif.

Keputusan Menteri Agama RI Nomor 118 Tahun 2014, tentang Pembentukan Badan Amil Zakat Nasional Provinsi. Keputusan Menteri Agama RI Nomor 333 Tahun 2015, tentang Pedoman Pemberian Izin Pembentukan Lembaga Amil Zakat.

Peraturan Menteri Agama RI Nomor 5 Tahun 2016, tentang Tatacara Pengenaan Sanksi Administratif dalam Pengelolaan Zakat.

Peraturan Menteri Agama RI Nomor 18 Tahun 2016, tentang Organisasi dan Tatakerja Sekretariat Badan Amil Zakat Nasional.

Keputusan Direktur Jenderal Bimbingan Masyarakat Islam Nomor DJ.III/499 Tahun 2016, tentang Perubahan 
Kedua Atas Kepdirjen Bimas Islam Nomor Dj.II/568 Tahun 2014, tentang Pembentukan Badan Amil Zakat Nasional, Kabupaten/Kota SeIndonesia.

Peraturan Menteri Dalam Negeri Nomor 32 Tahun 2011, tentang Pedoman Pemberian Hibah dan Bantuan Sosial yang Bersumber dari Anggaran Pendapatan dan Belanja Daerah.

Peraturan Direktur Jenderal Pajak Nomor: PER-33/PJ/2011 yang diubah dengan Perdirjen Pajak Nomor: PER15/PJ/2012, tentang Badan/Lembaga yang dibentuk atau Disahkan oleh Pemerintah yang Ditetapkan Sebagai Penerima Zakat atau Sumbangan Keagamaan yang Sifatnya Wajib yang Dapat Dikurangkan dari Penghasilan Bruto.

Peraturan Badan Amil Zakat Nasional Nomor 1 Tahun 2014, tentang Pedoman Tatacara Pengajuan Pertimbangan

Pengangkatan/Pemberhentian

Pimpinan Badan Amil Zakat Nasional Provinsi dan Badan Amil Zakat Nasional Kabupaten/Kota.

Peraturan Badan Amil Zakat Nasional Nomor 2 Tahun 2014, tentang Pedoman Tatacara Pemberian Rekomendasi Izin Pembentukan Lembaga Amil Zakat.

Peraturan Badan Amil Zakat Nasional Nomor 3 Tahun 2014, tentang Organisasi dan Tatakerja Badan Amil Zakat Nasional Provinsi dan Badan Amil Zakat Nasional Kabupaten/Kota.

Peraturan Badan Amil Zakat Nasional Nomor 4 Tahun 2014, tentang Pedoman Penyusunan Rencana Kerja dan Anggaran Tahunan Badan Amil Zakat Nasional, Badan Amil Zakat Nasional Provinsi, Badan Amil Zakat Nasional Kabupaten/Kota.
Fatwa:

Fatwa Majelis Ulama Indonesia Nomor 8 Tahun 2011, tentang Amil Zakat

Fatwa Majelis Ulama Indonesia Nomor 14 Tahun 2011, tentang Penyaluran Harta Zakat dalam Bentuk Aset Kelolaan.

Fatwa Majelis Ulama Indonesia Nomor 15 Tahun 2011, tentang Penarikan, Pemeliharaan dan Penyaluran Harta Zakat. 